Stony Brook University

Academic Commons

Library Faculty Publications

University Libraries

11-29-2016

\title{
How Do You Like Your Books: Print or Digital? An Analysis on Print and E-book Usage at The Graduate School of Education
}

Dana Haugh

SUNY Stony Brook, dana.haugh@stonybrook.edu

Follow this and additional works at: https://commons.library.stonybrook.edu/library_articles

Part of the Collection Development and Management Commons, Higher Education Commons, and the Information Literacy Commons

\section{Recommended Citation}

Haugh, Dana, "How Do You Like Your Books: Print or Digital? An Analysis on Print and E-book Usage at The Graduate School of Education" (2016). Library Faculty Publications. 5.

https://commons.library.stonybrook.edu/library_articles/5 
How Do You Like Your Books: Print or Digital?

An Analysis on Print and E-book Usage at The Graduate School of Education

Dana Haugh 


\begin{abstract}
The shift from physical materials to digital holdings has slowly infiltrated libraries across the globe, and librarians are struggling to make sense of these intangible, and sometimes fleeting, resources. Materials budgets have shifted to accommodate large journal and database subscriptions, single-title article access, and most recently, e-book holdings. This analysis measures the impact of digital acquisitions in an academic setting during a highly transformative period of library practices. The study finds that both electronic and print books are valuable to the academic research community at GSE.
\end{abstract}

Keywords: collection development, digital acquisitions, patron-drive, e-books, print books, access models, academic libraries

Author Note: Dana Haugh, Web Services Librarian, Stony Brook University, haugh.dana@gmail.com.

Received: December 2, 2015

Accepted: January 25, 2016 
How Do You Like Your Books: Print or Digital?

An Analysis on Print and E-book Usage at The Graduate School of Education

In academic libraries, the move from print subscriptions to digital subscriptions has been a natural progression. Despite the transient nature of digital holdings, libraries across the globe jumped on the electronic bandwagon, transforming a once physical and intellectual playground into an amalgamation of remotely accessible, intangibly immense, and fleetingly obtainable information available in an intimidating digital landscape. Libraries no longer face the immeasurable burden of procuring all information possible on a given topic; instead, librarians must focus their efforts on finding the requested information and ensuring both its reputability and veracity. Research institutions such as the Graduate School of Education (GSE) in New York City halted print journal subscriptions altogether in 2005/2006, preferring their digital counterparts, which give users access to thousands of articles in just a few clicks. Aggregators started offering package deals for database and journal subscriptions, encouraging libraries to obtain as many information resources as possible in order to appease the insatiable research population.

But the switch to digital subscriptions during the early 2000s was only the first step for the GSE in what was sure to be a materials overhaul. E-book collections, though less popular than their serials counterparts, were no doubt influenced by a prevalence of tablets and e-readers and steadily made their way into research libraries. The GSE began investigating the e-book's 
worth and presence in their academic collection and often were offered e-book package deals by aggregators from whom they already purchased journals and databases. These e-book packages offered impressive numbers of title holdings, which eventually influenced the school's decision to obtain these holdings in addition to their digital serials subscriptions. By 2009, the GSE made a bold and drastic change to its acquisitions policy:

As of 2009, faculty, students, and staff members will drive all future library acquisitions at the Graduate School of Education. The library endeavors to acquire all materials in digital form, as this is the preferred medium to support the widest possible use among library patrons. Requests will be fulfilled through the purchase of electronic journal articles, ebooks, digital journal subscriptions, or (if necessary) through interlibrary loan. In some cases where materials are not available in digital form, the library may purchase the materials in print, but print is increasingly being viewed as a last resort as digital materials are preferred for archival purposes (Graduate School of Education Collection Development Policy, 2014).

Not only did the research institution decide to adopt an entirely patron-driven acquisitions program, but it also endeavored to obtain any requested materials in single e-title digital formats only. The effects of this decision were dramatic. Physical materials acquisition dropped substantially in the first year of the policy's implementation as the push for digital purchases increased. Unfortunately, electronic versions of many requested titles were not available and, though the overall number of acquired materials was significantly lower than in previous years, print materials still made up $40 \%$ of the book budget during the first year, with the balance 
successfully allocated to digital copies. GSE did not renew its e-book package the following year (2010), as by that time the collection-development process relied solely on requests for titles that would be purchased as a single e-title or a print copy if unavailable.

Since the policy's inception, e-book acquisitions have represented between $40 \%$ to $60 \%$ of the college's book budget. But little research and investigation has been conducted on the success or failure of this digital collection's implementation. It is unclear whether these requested e-books are being used in a way that merits single-purchase only, if the library is properly allocating funds for e-purchases, whether package deals would better suit this acquisition endeavor, or if researchers prefer print copies of books over digital. Additionally, all e-book purchases are single-user subscriptions only, meaning that only one patron can view the e-book at a time, and turn-away rates have not been examined for patron access/usage. Unfortunately, without proper investigation the value of e-purchases and best practices for budget allocation may remain unknown. Due to the large percentage of funds dedicated to e-acquisition, it is important to fully research and analyze this area for potential problems or over-allocation of budgetary funds.

To garner a better understanding of the GSE's collection-development process and its overall effect on patron use and fulfillment, a comparison analysis will be conducted of print and digital materials of the same title within the collection. The researcher will extract data from both the graduate school's integrated library system (ILS) and ebrary accounts. This analysis will measure the impact of digital acquisitions in an academic setting during a highly transformative period of library practices. Analyzing this data will determine whether the digital e-book 
acquisitions model is a beneficial program in the library's collection process or if funds are being distributed to an unused, or underused, resource. Additionally, turn-away rates will be analyzed on single-user e-book titles to determine whether best practices for subscription access purchases should be adjusted to better suit community needs. Analysis of this data will better enable the materials and services teams at GSE to serve the academic community and its research desires. This data will also contribute to library's report for the year-end budget analysis, enabling the Head of Materials to forecast future fund distribution and the value of the e-book acquisition policy.

The findings in this data will largely affect how GSE will continue its materials and acquisitions purchases. However, due to the nature of the content, and the timeliness of e-book acquisitions processes in academic libraries, this analysis will contribute to the growing knowledge base of patron-driven, single-title e-book acquisitions in the general scope of libraries. By analyzing a small portion of data, the researcher will be able to develop grounds for further investigation into the college's holdings as well as provide a framework for investigation in academic libraries that wish to conduct a similar analysis.

\section{Research Questions}

The researcher endeavored to answer the following questions:

1. How many times is an e-book accessed compared to the checkout rate for a print material of the same title?

2. How many times is the average e-book viewed? 
3. What are the turnaway rates for the top five most accessed e-books? How many print books are there of the same title?

4. What is the cost comparison between e-book and print book?

\section{Overview of the GSE}

The GSE library is an academic research library that serves a community of graduate students, alumni, faculty, and staff. The GSE library is also accessible to members of affiliated institutions such as Ivy League University, Women's College, and the Religious Studies seminaries. The library is located within the GSE, next to the Ivy League University campus on the Upper West Side of Manhattan. All GSE members with an active ID are allowed full reading and borrowing privileges at the GSE library. There are 8,601 active GSE members as of May, 2014 , and $62.5 \%$ of these members have checked out library materials within the past year. There were approximately 510,000 visits to the GSE library between May, 2013 and April, 2014. The library's primary users are GSE graduate students of education (69\% master's students and $26 \%$ doctoral students) with a majority, $67 \%$ of students, studying part-time. The average graduate student age is 29 and approximately $76 \%$ of students are female.

All print materials are loaned on a semester basis, meaning that books can be, and often are, rented for an entire semester (approximately 4 months). Additionally, students can renew items from the print collection up to 10 times. If a book is checked out and no other copies are available, another student can choose to recall the book. A recall means that the current borrower has 10 days to return the book before being charged a penalty. Students wishing to use a highly 
trafficked book also have the option of submitting a materials request to obtain another copy of it for the library. If the materials department deems a request for extra copies is appropriate, the head of acquisitions will first attempt to acquire the material electronically, but if unsuccessful, an additional print copy will be purchased.

\section{Literature Review}

Libraries are now in a period of great transformation. As the line between physical and digital content continues to evolve, meld, and morph, libraries must navigate this contextual landscape to re-imagine their role in the lives of communities and academia. Information has never been so readily available and, in order to stay relevant, libraries must now compete with big-name knowledge aggregators like Google and Wikipedia. Characteristic Internet-age features like instant access, remote viewing, and accessibility have challenged libraries to deliver the same, if not better, content to their users. Materials budgets have shifted to accommodate large journal and database subscriptions, single-title article access, and most recently, e-book holdings.

This movement has had profound implications for academic libraries because, as Levine-Clark (2014) states, "libraries have opted to make available as broad a collection of material as possible by trading away the guarantee that those titles will be there for future generations of scholars" (p. 428). Academic libraries have reshaped their collection-development policies to reflect a holdings model more concerned with providing readily accessible, remotely viewable content to their users than with developing a tangible, permanent collection that not only serves their current users but will benefit future researchers. Patrons, researchers, scholars, 
and users have come to expect libraries to perform in the same way as Internet searches, providing instantaneous access to the information they seek.

\section{On-Demand Culture}

"In a world where a student can buy, download, and begin reading a Kindle book instantly or have a print book delivered in a day or two from Amazon . . . it is ludicrous to assume that students should not expect the same level of service from libraries" (Levine-Clark, 2014, p. 431). Acquiring digital materials in academic libraries is not new. Extensive, wide-ranging subscriptions to journals and databases providing hundreds of thousands of freely accessible articles have come to be the norm for most academic libraries. However, this need for on-demand service has infiltrated the e-book landscape as students begin to feel the seemingly "limited" capabilities of print books. As Ashcroft (2011) states, e-books provide "attractive features are akin to those for ejournals - including 24/7 availability and remote access.

Furthermore, just as users can access the particular article desired via ejournals, users can now access just the chapter or part desired from the ebook" (p. 406).

Digital accessibility gives researchers the flexibility to view, print, highlight, and analyze text when they want and wherever they are.

E-books offer 24/7 access to anyone with an Internet connection, allow for concurrent usage, and can be accessed from most portable devices. E-books are also easier to search, and the font can be adjusted to suit the user's personal preferences (Davies \& Morgan, 2013, p. 170). 
This enhanced level of personalization, coupled with ease of access and use, has encouraged academic libraries to consider adding digital versions of texts to their ever-growing electronic databases. Additionally, another study conducted at the University of Illinois found that students sought out e-books for the following advantages: "instant, desktop access (27\%), ability to keyword search (25\%), access from anywhere (17\%), portability (15\%), and environmentally better (7\%)" (Shelburne, 2009, p. 62). A study conducted over a 9-year period at the J. N. Desmarais Library of Laurentian University found that "patrons have always preferred online encyclopedias to their print equivalent" (Lamothe, 2013, p. 47). It is clear that there are innumerable benefits to acquiring electronic materials in addition to print resources, but the issue many librarians are facing now concerns how best to purchase these materials.

\section{Access Models for E-books}

Research has found that the profound shift from maintaining print collections to offering remotely accessible collections "is made possible by trends relating to long-term availability of monographs in the marketplace ... In many cases, a book not acquired when it is published can be purchased (often for a cheaper price) years later" (Levine-Clark, 2014, p. 429). The realization that books need not be purchased immediately upon publication has given libraries the flexibility to explore subscription-based access models, knowing monographs will likely be available for purchase at a later date. Libraries now have the freedom to forgo owning a monograph in favor of "leasing access to the book for the period of the license" (Simon, p. 71). 
This book "leasing" is a strange new development for collection expansion and often e-book acquisition policies are met with uncertainty.

Connaway and Wicht (2007) pointed to the "lingering insecurities" for purchasing e-books due to confusing business models that do not clarify ownership in perpetuity (18). They identified barriers to the adoption of e-books as 'lack of e-book and hardware standards; incompatible rights and operability; unrealistic price, purchase, and access models; and limited discovery and delivery options' (25) (Blummer \& Kenton, 2012, p. 67)

These are very real concerns felt by most librarians in the field, especially since e-books and monographs are similarly priced. There is no perpetuity in electronic books like there is with traditional books. Acquiring electronic books can almost be equated to leasing a car, in that payment does imply immediate, or even eventual, ownership. Furthermore, e-books maintain a certain level of mystery regarding usage and flexibility. York University found that

Faculty members were not actively promoting e-books to students and they wanted more information before recommending e-books. They were not sure if all students would be allowed concurrent access to an e-book for an unlimited amount of time. They had questions related to $24 / 7$ access policy, copyright, and downloading issues (Nariani, 2009)

This sentiment is also reflected by Walters (2014), who stated E-book licenses restrict not just the activities of individual patrons, but the ways in which e-books can be circulated and shared by university libraries. Common restrictions include 
limits on the number of simultaneous users; prohibitions on use by community (walk-in) patrons; limits on the number of times any particular title can be viewed; and limits on the use of e-books in course packs, as reserve readings, and in fulfillment of interlibrary loan requests (pp. 92-93)

These common concerns lead into the controversial subject of single- vs. multi-user subscriptions, which will be discussed later in the review.

\section{Acquiring E-books}

Although the process for acquiring digital books is not new, the advent of large-scale e-book acquisitions models and bundle packages has given many librarians pause. "Libraries began acquiring electronic books (e-books) in the middle to late 1990s, but until recently e-book acquisition provided only a small complement to the real business of buying print books" (Levine-Clark, 2014, p. 428). In the early stages of electronic implementation, libraries were acquiring e-books on an experimental basis and offering new-fangled digital representations to patrons on a much smaller scale. But with the turn of the century came new technologies, portability, and digital possibilities that influenced the popular "library in your pocket" thinking. Now, "librarians must have accurate knowledge about their users' concerns, which can be complex over the spectrum of ebooks, in order to obtain the 'right deal"' (Ashcroft, 2011, p. 406). Database and journal aggregators began offering thousands of e-books in package deals, impressing many librarians with the breadth and scope of their collections. These packages were 
undoubtedly impressive, but librarians many began questioning their worth as an electronic collection.

Librarians began considering e-book packages in regard to their delivery platforms, spending more time regarding their eventual "integration with other resources, download capability, the support for multiple file types, integration with the institutional repository or content management system, library hosted, PDF based, vendor hosted, and online only" (Blummer \& Kenton, 2012, p. 68). Librarians started digging deeper into e-book usage data and began noticing that considerable portions of these large e-book collections went unused. Aggregators may have briefly fooled acquisitions managers and librarians around the globe, offering these attractive, large-scale package-deals at one low price, but eventually librarians started fighting back, conducting their own research into the viability and worth of these mass-purchased titles. Concerns began shifting from providing as much content as possible to providing access only to frequently accessed materials. Swinburne University found that Where once liaison and reference librarians would spend considerable time selecting single book titles for firm order based on selection profiles, single-title selection is now focused largely on selecting a much smaller number of single titles identified as high-use candidates because they are on reading lists, linked from the learning management system, or identified as high-demand titles through reports of active hold requests in the library management system (Davies \& Morgan, 2013, p. 169) Additionally, they state "The most startling statistic we found after doing some analysis was that $100 \%$ of the autopurchased e-books had recorded use following purchase, while only $21 \%$ of the 
librarian-selected e-books recorded any use at all, and autopurchased e- books recorded much higher average use" (Davies \& Morgan, 2013, p.169). Employing such methods as DDA (data-driven acquisitions) and selective title purchasing began to override mass e-book package deals and oftentimes led to higher usage rates and lower costs per use.

The J.N. Desmarais Library found 'large 'viewings per e-book' and 'searches per e-book' ratios were observed when e-books were purchased selectively, on a title-by-title basis" (Lamothe, 2013, p. 55). As Levine-Clark (2014) points out, "to the extent possible, the preferred mode of acquisition will be DDA for monographs, articles, and any other material types" (p. 434). This method of e-books acquisitions is especially relevant for libraries restricted by budgets. Libraries have started to shy away from large packages, having quickly realized there is no need to provide access to thousands of titles that will never be accessed or even found inside their collection.

\section{Single- vs. Multi-User Subscriptions}

When purchasing access to e-books, libraries have the explicit choice in purchasing either single user or multi user access. This means that either one person or multiple people can view a book at any given time. Multi-user subscriptions are more expensive, which in many cases may act as a deterrent to those responsible for purchasing materials. As Walters (2014) points out, "the technological advantages of e-books are likely to be realized only to the extent that publishers and distributors can profit from them. Publishers are ultimately interested ... in limiting access in ways that generate revenue" (p. 89). 
This becomes especially frustrating for those who expect e-books to act similarly to their journal and article counterparts. Bucknell (2010) found that "library users . . expected to be able to view, download, and print e-book chapters just as they already did with e-journal articles: as DRM-free PDF files" (p. 126). Walters (2014) commented that "many students and faculty are unaware of even the most common restrictions on e-book access, sharing, and use" (p. 85). Blummer and Kenton (2012) found in multiple surveys and studies that a "lack of unlimited users for the University College Dublin library's instance of NetLibrary led to 'high turnaways' for some titles" (p. 75).

These misconceptions among users can lead to dissatisfaction, confusion, and even dissuade patrons from attempting to use these resources in the future. Ashcroft (2011) states that "although there are limits to the number of hard copies of a book that a library would purchase, it seems that, perhaps because of multiple ease of access to the Internet, limits to accessing ebooks are not recognized" (p. 402). There is also an added restriction found in e-book subscriptions that wouldn't normally arise with their print counterparts. For instance "the Educational Use provision of US copyright law gives faculty a limited right to make multiple copies for in-class use. Most e-book licenses include no such provision" (Walters, 2014, p. 90). Walters (2014) also points out that "e-book licenses restrict not just the activities of individual patrons, but the ways in which e-books can be circulated and shared by university libraries” (pp. 92-93).

Ultimately, however, the choice between purchasing single access or multi-access subscriptions depends on the budgetary allowances for a specific library. Librarians must determine the best course of action for their library regarding individual titles or package deals 
that will serve their community most effectively. Usage rates, materials for course reserves, and overall title popularity should all be considered when making the choice between single or multi user subscriptions.

\section{Summary}

E-book acquisitions pose a number of benefits as well as concerns for librarians in the academic space. It is clear that as time progresses and access models evolve, so too, will the acquisitions policies for these ever-changing, impermanent resources. It is important for librarians to consider a wide-range of data in order to determine the right e-book acquisitions policy for their library. Purchasing large collections of e-titles may seems attractive, but if the titles are not being accessed, a library may find their budget better spent on acquiring popular single title e-books or multiple access subscriptions.

\section{Findings}

E-book Usage Compared to Print-Book Checkouts. The first question to be addressed is:

1. How many times is an e-book accessed compared to the checkout rate for a print material of the same title?

In order to determine this number, the researcher pulled usage statistics from ebrary on the library's e-book holdings, crosschecked the most frequently accessed e-book titles with print counterparts, pulled data on print circulation for books of the same title, and compared the findings for data analysis. Data for print-book circulation was only available from 2013 until present, so the usage numbers for each format reflect statistics generated from January 1, 2013 to 
October 1, 2014. [Figure 1] displays the results for each format in the given parameters. It should be noted that e-book numbers have been divided by 100 to account for less-frequent circulation of print books due to 4-month loan periods and to provide a better visual comparison between the two formats. Additionally, book 4 was omitted from the chart due to an unusually high print circulation. [Figure 6] displays the following information: figures used to compile [Figure 1]; titles of books 1-19; number of e-book sessions; number of print book circulations; e-book access type; number of print copies. Usage statistics for print titles with more than one physical copy in the library have been merged to form a total number of circulations for all copies.

As seen in [Figure 1], most e-book titles were accessed more frequently than their print counterparts. Only six print titles (including book 4 which is not shown on the table) "outperformed" e-books of the same title (after the e-book numbers were adjusted to account for the 4-month check-out periods which substantially restrict print circulation). As shown in [Figure 6], the library carries anywhere from two to four print copies of the six book titles that outperformed e-book usage (books $2,4,6,11,14,19$ ). Interestingly, only two out of the six e-books of the same title were restricted by "single user" access, showing that unlimited access in these cases was less beneficial as print books were preferred. [place figure 1 here]

Interpretations. This chart supports the notion that patrons will access e-books even though print books of the same title exist within the library. This chart also supports the idea that, in most cases, students are more likely to access e-books even when access is limited to "single user" only. As seen in [Figure 6], books 2, 5, 7, 12, 14, 17, and 18 all are limited to single user 
access as e-books. [Table 1] displays all single-user e-title session numbers (divided by 100) alongside print circulations of the same title, as well as a simple ratio comparing the two numbers.

[place table 1 here]

As shown in [Table 1], excluding books 2 and 14, single-user e-book titles still outperformed their print counterparts substantially. The library only carries one print copy of books 7,12 , and 17 which explains why the e-book titles outperformed print circulation at a slightly higher percentage than the others seen in [Table 1]. The GSE library carries three print copies of book 2 and book 14, and though the print copies performed slightly better than the e-book titles, it is clear that these titles are in high demand, and users would benefit from unlimited subscription access for these e-books.

[Table 2] shows books $1,3,7,12,16$, and 17 of which the library only has one print copy. The books highlighted represent single-user e-book access while the remaining titles have unlimited e-book access. Once again, all e-book session numbers have been divided by 100 to accommodate for print loan periods.

[place table 2 here]

As seen in [Table 2], e-books with unlimited subscription access models are more likely to see a wider usage ratio when compared to single-print copies. Additionally, books that have unlimited access, predictably have a higher session number than those with only single-user access (excluding book 16). 
Verdict. After analyzing circulation and session rates for 19 books in the GSE's collection, it is clear that both print and electronic books are valuable resources to the academic community. There is a slight correlation between high e-book usage when only one print copy is available in the library's collection, but this supposition isn't conclusive given the small amount of single-print copies in this book sampling. For the two print books that substantially outperformed their electronic counterparts (books 4 and 19), the library carries two print copies of each title and unlimited access models for each digital title. It is unclear why these print titles performed so much better than their electronic counterparts, though the researcher suspects that both titles may have been popular course reserves during the past 2 years.

\section{Average E-book Access}

\section{Question 2 asks:}

2. How many times is the average e-book viewed?

In order to calculate this number, the researcher opted to gather statistics for all successful GSE e-book sessions from January 1, 2013, to October 1, 2014. This report was compiled using "Book report 2" on ebrary's administrator panel with a custom date range from $1 / 1 / 13$ to $10 / 1 / 4$. In the case of this report, "success" implies that a user successfully viewed an e-book. As all digital acquisitions are patron-driven, this figure will also represent the total number of digital e-book holdings for the GSE library. The report resulted in approximately 10,006 e-book titles, with session numbers ranging from 1 to 8,560. [Table 3] shows the distribution of view counts in relation to the associated number of titles. [place table 3 here] 
Interpretations. As shown in [Table 3], 17.5\% of e-books held by GSE have been viewed only once since January 1, 2013. Over 50\% of the e-title holdings have been viewed 10 times or fewer, and the most frequently viewed digital titles make up only $1.18 \%$ of the digital collection. E-books with 11-99 sessions make up $37.5 \%$ of the total collection views and the average view count for e-books is 66 . This number is considerably higher than it should be given that over $50 \%$ of e-books are viewed 10 times or fewer. This is likely due to the large outliers that represent $.18 \%$ of the collection. In order to get a better estimate, the researcher calculated the average for $98.82 \%$ of the collection, excluding views over 1,000 , which resulted in a more accurate average of 42 sessions per e-book. Of the top 18 highest viewed e-books, six of those titles are single-user access only. [Figure 7] lists the titles of the top 18 most viewed e-books, associated view counts, and subscription access. Items highlighted in yellow

Verdict. As displayed in [Table 3], a startling percentage of held e-books have been viewed only once in the past 21 months and approximately $52 \%$ of all holdings have been viewed up to 10 times. Unsurprisingly, e-books with a high session count make up only a very small percentage of the GSE holdings; however, most e-books are being accessed an average of 42 sessions per title in a span of 21 months. This is solid number, considering e-titles are not promoted or displayed on the library's webpage and are being found only through catalog searches. The highest view counts are likely due to required class readings and course reserve materials, and of those 18 titles there are six that are limited to single-access. Those six titles should be evaluated for turnaway rates and request frequency in order to determine if multi-user access should be granted. 


\section{Top Turnaway Rates}

\section{Question 3 asks:}

3. What are the turnaway rates for the top five most accessed e-books? How many print books are there of the same title?

Turnaway statistics are generated when a patron attempts to view a single-user e-book that is "already in use." In other words, another patron is already viewing the book and therefore prevents future patrons from accessing the title at the same time. In order to determine the top five most accessed, single-user e-books, the researcher identified the top five single-user e-books listed in [Figure 7] and ran a report in ebrary on all turnaways between January 1, 2013 and October 1, 2014. From there, the researcher cross-checked the five titles with the resulting turnaway list. [Table 4] displays her findings. It should be noted that the titles listed in [Figure 7] were generated based solely on e-book usage and do not necessarily exist in print form. Although there is overlap between figures 6 and 7 regarding titles, the two tables should be regarded separately. Additionally, the titles in [Table 4] are ordered from highest accessed to lowest access, according to usage rates in [Figure 7].

[place table 4 here]

Interpretations. As shown in Table 4, 60\% of the highest viewed e-books do not exist in print form in the library. The highest turnaway rate, 15 for Learning About Learning Disabilities, is not available in print form, limiting patrons to e-book access only. This may explain why the number of turnaways is so high. A total of 134 titles generated turnaway rates ranging from 1 to 
18 times during the 21 -month period. The highest turnaway rate (18 turnaways) ranks as the $36^{\text {th }}$ highest viewed title (which falls within the highest 1.18\% of e-holdings, according to [Table 3]) with two print copies available in the library; titles with the lowest turnaway rates (1 turnaway) fall within the 11-999 session category and range from 0-3 print copies available in the GSE library.

Verdict. Analysis of the five highest viewed e-books with single-access subscriptions shows that approximately 54 patrons were denied access to these popular titles. Additionally, for $60 \%$ of these titles, electronic access was the only format offered. This chart shows that users are attempting to access these titles digitally but are being driven away by limited-access models. In previous years, when a title has been requested multiple times or is in high demand, the GSE library purchased a second copy of a title to be put into circulation. In light of the high turnaway rates for these titles, and limited electronic-only access for three out of five, the GSE library should consider purchasing multi-user access to these titles to better serve the community. Additionally, the library should consider purchasing multi-access subscriptions for e-books ranking in the highest $1.18 \%$ of session views that have generated turnaway statistics.

\section{Cost Comparison: Print vs. Electronic}

\section{Question 4 asks:}

4. What is the cost comparison between e-books and print books?

In order to compile a table of cost comparisons between e-books and print books, the researcher extracted prices from YBP Library Services (GSE's e-book vendor) for the ebrary platform and then recorded the price of each print book listed in the library's catalog and ILS, 
Sierra. For a better comparison, the researcher included price points for both single and multi user e-book access, both extracted from YBP. [Table 8], located in Appendix C, displays the full list of the original 19 titles with cost comparisons for each, while Table 5 below displays the first five books from that table.

[place table 5 here]

Books 2 and 5 are highlighted to indicate that the library has a single-access subscription to these titles and the asterisk indicates that only 3-user access is available for these titles, as opposed to unlimited access. Additionally, all highlighted titles in [Table 8], also denote single-user access through the GSE subscription. It should also be noted that books 2 and 5 appear in [Table 4] regarding turnaway rates and rank $3^{\text {rd }}$ and $4^{\text {th }}$ respectively on that list. Interpretations. According to this analysis, $100 \%$ of print books in this sample are less expensive than their e-book counterparts. When comparing single access e-books to print books, e-books are priced anywhere from $\$ 1.92$ to $\$ 220.09$ more than print books. When comparing print to multi-access e-books, buyers can acquire anywhere from 2 to 15 print copies per multi-access subscription. It is clear that e-books hold a price point significantly higher than their print counterparts, especially considering their transient nature. It also becomes clear why the GSE library opted for single user access in the case of books 2, 5, 7, 12, 14, 17, and 18, as each of these books did not offer an unlimited access model; instead, the significantly higher price point earned buyers only a 3-user access model.

Verdict. E-books are revealed to be significantly more expensive than print books in this sampling from the GSE catalog. Unlimited-access models make the most sense for these high 
trafficked titles, as they meet the demands of the academic community's research needs. All titles on this list have at least one print counterpart available in the library, which can fulfill the needs of those who prefer reading print over electronic. However, titles that are restricted by single-access e-book models should be offset with at least two print copies available in the library to accommodate limited online viewing. Books 7, 12, and 17 are each restricted to one print copy and single-user access. Given that print copies of these titles are so inexpensive, the GSE library should acquire at least one extra copy of each title to meet the needs of the research community.

\section{Summary of Findings and Recommendations}

Extensive analysis of e-book usage, turnaway rates, and cost comparisons has revealed many important insights into the GSE library collection. First, this analysis concludes that the patron-driven, digital acquisitions model put into place in 2009 can be deemed a success, as the majority of digital holdings are being viewed more than one time, without any promotional work or e-book marketing. The success of this patron-driven model proves that the GSE community is $82.5 \%$ likely to view an e-book requested from a fellow academic more than once in a 21 -month period, as shown in [Table 3]. This is excellent news, given that e-books are much more expensive than print holdings. The high return visit percentage proves that the GSE library is allocating funds appropriately for their collection. An additional study focusing on the circulation of materials only available in print would be a valuable companion to this analysis and could further support the value e-book holdings. 
For the top $.18 \%$ of materials with single-access models that have also generated turnaway statistics, the researcher will propose acquiring multi-user access models to better suit community needs. Additionally, for the items with high turnaway rates that do not have print copies available in the library, the researcher will propose acquiring one print copy for these titles to offset limited availability.

This study concludes that both electronic and print books are valuable to the academic research community. It was important to conduct a study comparing the two formats in order to establish current user preference and forecast future user trends in the overall collection development of the library. While it is clear that many researchers enjoy the accessibility of e-books, print books of the same title are still circulating (and at relatively high rates), proving that this format, and its incomparable legacy, is not going anywhere.

\section{Summary}

The purpose of this study was to analyze and interpret data from the GSE on patron usage of print and electronic books of the same title. This study analyzed 19 titles available in both print and digital formats for in order to determine the effectiveness of the patron-driven, digital acquisitions initiative that was implemented in 2009 in the GSE library. To address concerns such as overall usage, print or digital preference, value of electronic holdings, and proper allocation of funds, the researcher then conducted a thorough literature review on e-book usage in other academic and public libraries in order to garner a broad understanding of e-book/print book usage and perceptions. The review explored six main topics that are important in e-book research today: on-demand culture, access models for e-books, acquiring e-books, single vs. 
multi user subscriptions, e-book collection visibility, and the print vs. digital debate. After reviewing these areas, the researcher compiled statistics and extracted numbers from the GSE's catalog, ILS, and e-book vendors in order to answer the research questions. After significant analysis and review, and revisiting the initial hypotheses made, the researcher concluded that:

1. The GSE library is not over-allocating funds to e-book acquisitions. Although a significant number of titles $(17.5 \%)$ have been accessed only once in a 21 -month period, the majority of the collection is being viewed two or more times, with an average of 42 sessions per title. The majority of the highest viewed e-book titles have unlimited subscription models. A small number of titles that do not have unlimited access models because it is not offered; instead, three-user subscriptions are offered for these titles, and the library chose to forgo this option.

2. There are many single-title items with high access rates that have also generated high turnaway rates during the last 21 months. In the case of some titles, an unlimited access model was not available. However, in other cases the library may wish to revisit these titles and determine the best course of action for community needs.

3. The print counterparts of the 19 examined titles are still circulating. This discovery shows that even though electronic access is available, patrons are still actively using print materials in the library. The academic community still values the tangible quality of print books despite the unlimited access models, remote accessibility, and search functions of their electronic equivalents.

\section{Conclusions}


This study concluded that print and e-books can coexist in an academic research library, and patrons will still find value in both formats. The patron-driven, digital acquisitions model is successfully acquiring materials that researchers in the academic community will use and revisit in the years to come. Even though electronic materials are more expensive than print copies, the added accessibility value clearly justifies its price point. Additionally, driving all acquisitions based on patron-specific requests ensures that every item the library acquires, in print and electronically, is used at least one time. The GSE library's access model is currently allocating funds to support both its current researchers and future generations of researchers. The transient nature of e-books is worrisome; but if these resources are being used in a way that warrants their purchase, like those at the GSE library, then their service to today's research community is priceless. This is not the end of print books; rather, this is the beginning of a peaceful coexistence where everyone's needs are met in a way that best suits them. 


\section{References}

Ashcroft, L. (2011). Ebooks in libraries: An overview of the current situation. Library Management, 32(6), 398-407.

Blummer, B. \& Kenton, J. (2012). Best practices for integrating e-books in academic libraries: A literature review from 2005 to present. Collection Management, 37(2), 65-97.

Bucknell, T. (2010). The big-deal approach to acquiring e-books: A usage-based package. Serials, 23(2), 126-134.

Davies, T., \& Morgan, M. (2013). Ebooks down under. In Proceedings of 'Too Much Is Not Enough!', the 33rd Annual Charleston Conference: Issues in Book and Serial Acquisition. Charleston, South Carolina, United States.

Lamothe, A. (2013). Factors influencing the usage of an electronic book collection: Size of the e-book collection, the student population, and the faculty population. College \& Research Libraries, 74(1), 39-59.

Levine-Clark, M.(2014). Access to everything: Building the future academic library collection. Libraries and the Academy, 14(3), 425-437.

Nariani, R. (2009). E-books in the sciences: If we buy it will they use it? Issues in Science and Technology Librarianship. Retrieved from http://www.istl.org/09-fall/article3.html

Shelburne, W. A. (2009). E-book usage in an academic library: User attitudes and behaviors. Library Collections, Acquisitions, and Technical Services, 33(2), 59-72. 
Simon, J. (2014). E-book purchasing best practices for academic libraries. Journal of Electronic Resources Librarianship, 26(1), 68-77.

Walters, W. (2014). E-books in academic libraries: Challenges for sharing and use. Journal of Librarianship and Information Science, 46(2), 85-95.

Figure 9

\section{Appendix A}

\section{Title Information}

\begin{tabular}{|c|c|c|c|c|}
\hline $\begin{array}{l}\text { Book } \\
\text { number }\end{array}$ & Title & Publisher & Online Access & GSE Copies \\
\hline Book 1 & Evidence-Based Educational Methods & $\begin{array}{l}\text { Elsevier Science \& } \\
\text { Technology Books }\end{array}$ & Unlimited & 1 copy \\
\hline Book 2 & $\begin{array}{l}\text { Language, Culture, and Teaching: } \\
\text { Critical Perspectives for a New Century: } \\
\text { (2nd ed.) }\end{array}$ & Routledge & Single User & $\begin{array}{l}3 \text { copies - one copy } \\
\text { on reserve }\end{array}$ \\
\hline Book 3 & $\begin{array}{l}\text { Enhancing Professional Practice: A } \\
\text { Framework for Teaching (2nd Edition) }\end{array}$ & $\begin{array}{l}\text { Association for } \\
\text { Supervision \& } \\
\text { Curriculum } \\
\text { Development }\end{array}$ & Unlimited & 1 copy \\
\hline Book 4 & $\begin{array}{l}\text { Understanding by Design (Expanded 2nd } \\
\text { ed.) }\end{array}$ & $\begin{array}{l}\text { Association for } \\
\text { Supervision \& } \\
\text { Curriculum } \\
\text { Development }\end{array}$ & Unlimited & 2 copies \\
\hline Book 5 & $\begin{array}{l}\text { Funds of Knowledge: Theorizing } \\
\text { Practices in Households, Communities, } \\
\text { and Classrooms }\end{array}$ & $\begin{array}{l}\text { Lawrence Erlbaum } \\
\text { Associates, } \\
\text { Incorporated }\end{array}$ & Single User & 3 copies \\
\hline Book 6 & $\begin{array}{l}\text { Cambridge Handbook of the Learning } \\
\text { Sciences }\end{array}$ & $\begin{array}{l}\text { Cambridge } \\
\text { University Press }\end{array}$ & Unlimited & 4 copies \\
\hline Book 7 & $\begin{array}{l}\text { Relational Perspectives Book: Analyst in } \\
\text { the Inner City: Race, Class, and Culture } \\
\text { Through a Psychoanalytic Lens ( } 2 \text { nd ed.) }\end{array}$ & Psychology Press & Single User & 1 copy \\
\hline Book 8 & Craft of Research (3rd ed.) & $\begin{array}{l}\text { University of } \\
\text { Chicago Press }\end{array}$ & Unlimited & 3 copies \\
\hline Book 9 & $\begin{array}{l}\text { Making Space: Merging Theory and } \\
\text { Practice in Adult Education }\end{array}$ & Greenwood Press & Unlimited & 2 copies \\
\hline Book 10 & $\begin{array}{l}\text { Globalization: Culture and Education in } \\
\text { the New Millennium }\end{array}$ & $\begin{array}{l}\text { University of } \\
\text { California Press }\end{array}$ & Unlimited & 4 copies \\
\hline
\end{tabular}




\begin{tabular}{|c|c|c|c|}
\hline $\begin{array}{l}\text { Contradictory College: The Conflicting } \\
\text { Book } 11 \text { Origins, Impacts, and Futures of the } \\
\text { Community College }\end{array}$ & $\begin{array}{l}\text { State University of } \\
\text { New York Press }\end{array}$ & Unlimited & 3 copies \\
\hline Book $12 \begin{array}{l}\text { Bilingual Education: From Compensatory } \\
\text { to Quality Schooling (2nd ed.) }\end{array}$ & $\begin{array}{l}\text { Lawrence Erlbaum } \\
\text { Associates, } \\
\text { Incorporated }\end{array}$ & Single User & 1 copy \\
\hline $\begin{array}{l}\text { Book } 13 \text { Learning Disabilities: From Identification } \\
\text { to Intervention }\end{array}$ & Guilford Press & Unlimited & 2 copies \\
\hline $\begin{array}{l}\text { Book } 14 \text { Teaching ESL Composition: Purpose, } \\
\text { Process, and Practice }\end{array}$ & $\begin{array}{l}\text { Lawrence Erlbaum } \\
\text { Associates, } \\
\text { Incorporated }\end{array}$ & Single User & 3 copies \\
\hline $\begin{array}{l}\text { Integrating Differentiated Instruction and } \\
\text { Book } 15 \text { Understanding by Design: Connecting } \\
\text { Content and Kids }\end{array}$ & $\begin{array}{l}\text { Association for } \\
\text { Supervision \& } \\
\text { Curriculum } \\
\text { Development }\end{array}$ & Unlimited & 2 copies \\
\hline $\begin{array}{l}\text { Checking for Understanding: Formative } \\
\text { Book 16 Assessment Techniques for Your } \\
\text { Classroom }\end{array}$ & $\begin{array}{l}\text { Association for } \\
\text { Supervision \& } \\
\text { Curriculum } \\
\text { Development }\end{array}$ & Unlimited & 1 copy \\
\hline $\begin{array}{l}\text { Book } 17 \text { Creativity in the Classroom: Schools of } \\
\text { Curious Delight }\end{array}$ & $\begin{array}{l}\text { Lawrence Erlbaum } \\
\text { Associates, } \\
\text { Incorporated }\end{array}$ & Single User & 1 copy \\
\hline Book 18 Handbook of Reading Research & Routledge & Single User & 2 copies \\
\hline $\begin{array}{l}\text { Book } 19 \text { Unequal Childhoods: Class, Race, and } \\
\text { Family Life }\end{array}$ & $\begin{array}{l}\text { University of } \\
\text { California Press }\end{array}$ & Unlimited & 2 copies \\
\hline
\end{tabular}




\section{Appendix B}

Figure 6.

Electronic and Print Title Comparison

\begin{tabular}{|c|c|c|c|c|c|}
\hline$\#$ & Title & $\begin{array}{c}\text { \# of E-book } \\
\text { Sessions }\end{array}$ & $\begin{array}{c}\text { \# of Print } \\
\text { Circulations }\end{array}$ & $\begin{array}{c}\text { E-book } \\
\text { Access Type }\end{array}$ & $\begin{array}{c}\text { \# of Prin } \\
\text { Copies }\end{array}$ \\
\hline 1 & $\begin{array}{l}\text { Evidence-Based Educational } \\
\text { Methods (1st ed.) }\end{array}$ & 6,236 & 17 & Unlimited & 1 copy \\
\hline 2 & $\begin{array}{c}\text { Language, Culture, and Teaching: } \\
\text { Critical Perspectives for a New } \\
\text { Century (2nd ed.) }\end{array}$ & 5367 & 73 & Single User & 3 copies \\
\hline 3 & $\begin{array}{l}\text { Enhancing Professional Practice: A } \\
\text { Framework for Teaching (2nd ed.) }\end{array}$ & 4676 & 10 & Unlimited & 1 copy \\
\hline 4 & $\begin{array}{l}\text { Understanding by Design (Expanded } \\
\text { 2nd ed.) }\end{array}$ & 4,260 & 214 & Unlimited & 2 copies \\
\hline 5 & $\begin{array}{l}\text { Funds of Knowledge: Theorizing } \\
\text { Practices in Households, } \\
\text { Communities, and Classrooms }\end{array}$ & 3,355 & 22 & Single User & 3 copies \\
\hline 6 & $\begin{array}{l}\text { Cambridge Handbook of the } \\
\text { Learning Sciences (1st ed.) }\end{array}$ & 3,131 & 35 & Unlimited & 4 copies \\
\hline 7 & $\begin{array}{l}\text { Relational Perspectives Book: } \\
\text { Analyst in the Inner City: Race, } \\
\text { Class, and Culture Through a } \\
\text { Psychoanalytic Lens (2nd ed.) }\end{array}$ & 2,872 & 6 & Single User & 1 copy \\
\hline 8 & Craft of Research (3rd ed.) & 2,549 & 17 & Unlimited & 3 copies \\
\hline 9 & $\begin{array}{l}\text { Making Space: Merging Theory and } \\
\text { Practice in Adult Education }\end{array}$ & 2,441 & 25 & Unlimited & 2 copies \\
\hline 10 & $\begin{array}{l}\text { Globalization: Culture and Education } \\
\text { in the New Millennium }\end{array}$ & 2,431 & 22 & Unlimited & 4 copies \\
\hline 11 & $\begin{array}{l}\text { Contradictory College: The } \\
\text { Conflicting Origins, Impacts, and } \\
\text { Futures of the Community College }\end{array}$ & 2,355 & 31 & Unlimited & 3 copies \\
\hline 12 & $\begin{array}{c}\text { Bilingual Education: From } \\
\text { Compensatory to Quality Schooling } \\
\text { (2nd ed.) }\end{array}$ & 2,317 & 13 & Single User & 1 copy \\
\hline 13 & $\begin{array}{l}\text { Learning Disabilities: From } \\
\text { Identification to Intervention }\end{array}$ & 2,202 & 14 & Unlimited & 2 copies \\
\hline 14 & $\begin{array}{l}\text { Teaching ESL Composition: } \\
\text { Purpose, Process, and Practice }\end{array}$ & 2,192 & 27 & Single User & 3 copies \\
\hline
\end{tabular}




\begin{tabular}{|c|c|c|c|c|c|}
\hline 15 & $\begin{array}{l}\text { Integrating Differentiated Instruction } \\
\text { and Understanding by Design: } \\
\text { Connecting Content and Kids }\end{array}$ & 1,914 & 14 & Unlimited & 2 copies \\
\hline 16 & $\begin{array}{c}\text { Checking for Understanding: } \\
\text { Formative Assessment Techniques } \\
\text { for Your Classroom }\end{array}$ & 1,483 & 5 & Unlimited & 1 copy \\
\hline 17 & $\begin{array}{l}\text { Creativity in the Classroom: Schools } \\
\text { of Curious Delight }\end{array}$ & 1,253 & 5 & Single User & 1 copy \\
\hline 18 & Handbook of Reading Research & 980 & 7 & Single User & 2 copies \\
\hline 19 & $\begin{array}{c}\text { Unequal Childhoods: Class, Race, } \\
\text { and Family Life }\end{array}$ & 940 & 26 & Unlimited & 2 copies \\
\hline
\end{tabular}

Figure 7.

E-book Session Count and Access Type

\begin{tabular}{|c|c|c|}
\hline Title & $\begin{array}{c}\text { Sessions } \\
(\mathbf{1} / \mathbf{1} / \mathbf{1 3 - 1 0 / 1 / 1 4 )}\end{array}$ & $\begin{array}{c}\text { Subscription } \\
\text { Access }\end{array}$ \\
\hline $\begin{array}{c}\text { Bilingual Education and Bilingualism: An Ecological Framework for } \\
\text { Educational Policy, Research and Practice in Multilingual Settings }\end{array}$ & 8,560 & Unlimited \\
\hline Evidence-Based Educational Methods & 6,236 & Unlimited \\
\hline $\begin{array}{c}\text { Language, Culture, and Teaching: Critical Perspectives for a New Century } \\
\text { (2nd ed.) }\end{array}$ & 5,367 & Single User \\
\hline Keaming: How Organizations Learn, Innovate, and Compete in the & 4,949 & Unlimited \\
\hline Enhancing Professional Practice: A Framework for Teaching (2nd ed.) & 4,676 & Unlimited \\
\hline Understanding by Design (Expanded 2nd ed.) & 4,260 & Unlimited \\
\hline Learning about Learning Disabilities (4th ed.) & & Unlimited \\
\hline Tinkering Toward Utopia: A Century of Public School Reform & & Unlimited \\
\hline
\end{tabular}




\begin{tabular}{|c|c|c|}
\hline CourseSmart: Case Studies in Multicultural Counseling and Therapy & 3,779 & Unlimited \\
\hline Group Creativity: Innovation through Collaboration & 3,759 & Unlimited \\
\hline Counseling Adults in Transition: Linking Practice with Theory (3rd ed.) & 3,722 & Unlimited \\
\hline Child and Adolescent Psychopathology (2nd ed.) & 3,576 & Unlimited \\
\hline Regression Analysis by Example (4th ed.) & 3,490 & Single User \\
\hline Funds of Knowledge: Theorizing Practices in Households, Communities, & 3,355 & Single User \\
and Classrooms & & Single User \\
\hline Second Language Acquisition: An Introductory Course (3rd ed.) & 3,288 & Unlimited \\
\hline Cambridge Handbook of the Learning Sciences & 3,157 & Single User \\
\hline
\end{tabular}

\section{Appendix C}

Table 8.

Electronic and Print Title Cost Comparison

\begin{tabular}{|c|c|c|c|c|}
\hline \# & Title & $\begin{array}{l}\text { Print Book } \\
\$\end{array}$ & $\begin{array}{c}\text { E-book Single } \\
\text { Access \$ }\end{array}$ & $\begin{array}{l}\text { E-book Multi } \\
\text { Access \$ }\end{array}$ \\
\hline 1 & Evidence-Based Educational Methods & $\$ 87.43$ & $\$ 115.14$ & $\$ 172.71$ \\
\hline 2 & $\begin{array}{l}\text { Language, Culture, and Teaching: Critical } \\
\text { Perspectives for a New Century (2nd ed.) }\end{array}$ & $\$ 56.00$ & $\$ 160.00$ & $\$ 200.00 *$ \\
\hline 3 & $\begin{array}{c}\text { Enhancing Professional Practice: A Framework } \\
\text { for Teaching (2nd ed.) }\end{array}$ & $\$ 26.03$ & $\$ 27.95$ & $\$ 41.93$ \\
\hline 4 & Understanding by Design (Expanded 2nd ed.) & $\$ 27.90$ & $\$ 32.95$ & $\$ 49.43$ \\
\hline 5 & $\begin{array}{l}\text { Funds of Knowledge: Theorizing Practices in } \\
\text { Households, Communities, and Classrooms }\end{array}$ & $\$ 48.85$ & $\$ 135.00$ & $\$ 168.75 *$ \\
\hline 6 & Cambridge Handbook of the Learning Sciences & $\$ 61.76$ & $\$ 195.00$ & - \\
\hline
\end{tabular}




\begin{tabular}{|c|c|c|c|c|}
\hline 7 & $\begin{array}{l}\text { Relational Perspectives Book: Analyst in the } \\
\text { Inner City: Race, Class, and Culture Through a } \\
\text { Psychoanalytic Lens (2nd ed.) }\end{array}$ & $\$ 41.00$ & $\$ 145.00$ & $\$ 181.25^{*}$ \\
\hline 8 & Craft of Research (3rd ed.) & $\$ 9.86$ & $\$ 45.00$ & $\$ 67.50$ \\
\hline 9 & $\begin{array}{l}\text { Making Space: Merging Theory and Practice in } \\
\text { Adult Education }\end{array}$ & $\$ 41.11$ & $\$ 130.85$ & $\$ 196.28$ \\
\hline 10 & $\begin{array}{l}\text { Globalization: Culture and Education in the } \\
\text { New Millennium }\end{array}$ & $\$ 35.60$ & $\$ 55.00$ & $\$ 82.50$ \\
\hline 11 & $\begin{array}{l}\text { Contradictory College: The Conflicting Origins, } \\
\text { Impacts, and Futures of the Community College }\end{array}$ & $\$ 24.50$ & $\$ 64.50$ & $\$ 129.00$ \\
\hline 12 & $\begin{array}{l}\text { Bilingual Education and Bilingualism: An } \\
\text { Ecological Framework for Educational Policy, } \\
\text { Research and Practice in Multilingual Settings }\end{array}$ & $\$ 28.88$ & $\$ 101.95$ & $\$ 127.44^{*}$ \\
\hline 13 & $\begin{array}{c}\text { Learning Disabilities: From Identification to } \\
\text { Intervention }\end{array}$ & $\$ 35.73$ & $\$ 92.00$ & - \\
\hline 14 & $\begin{array}{c}\text { Teaching ESL Composition: Purpose, Process, } \\
\text { and Practice }\end{array}$ & $\$ 44.99$ & $\$ 209.95$ & $\$ 262.44^{*}$ \\
\hline 15 & $\begin{array}{c}\text { Integrating Differentiated Instruction and } \\
\text { Understanding by Design: Connecting Content } \\
\text { and Kids }\end{array}$ & $\$ 19.55$ & $\$ 25.95$ & $\$ 51.90$ \\
\hline 16 & $\begin{array}{l}\text { Checking for Understanding: Formative } \\
\text { Assessment Techniques for Your Classroom }\end{array}$ & $\$ 19.99$ & $\$ 26.95$ & $\$ 53.90$ \\
\hline 17 & $\begin{array}{c}\text { Creativity in the Classroom: Schools of Curious } \\
\text { Delight }\end{array}$ & $\$ 12.99$ & $\$ 185.95$ & N/A \\
\hline 18 & Handbook of Reading Research & $\$ 109.91$ & $\$ 330.00$ & $\$ 412.50 *$ \\
\hline 19 & $\begin{array}{l}\text { Unequal Childhoods: Class, Race, and Family } \\
\text { Life }\end{array}$ & $\$ 23.18$ & $\$ 55.00$ & $\$ 82.50$ \\
\hline
\end{tabular}

* Indicates price is for 3-user access (unlimited access not available)

- Indicates price was unavailable

\section{Appendix D}

Figure 1. E-book vs. Print Book Circulation. 


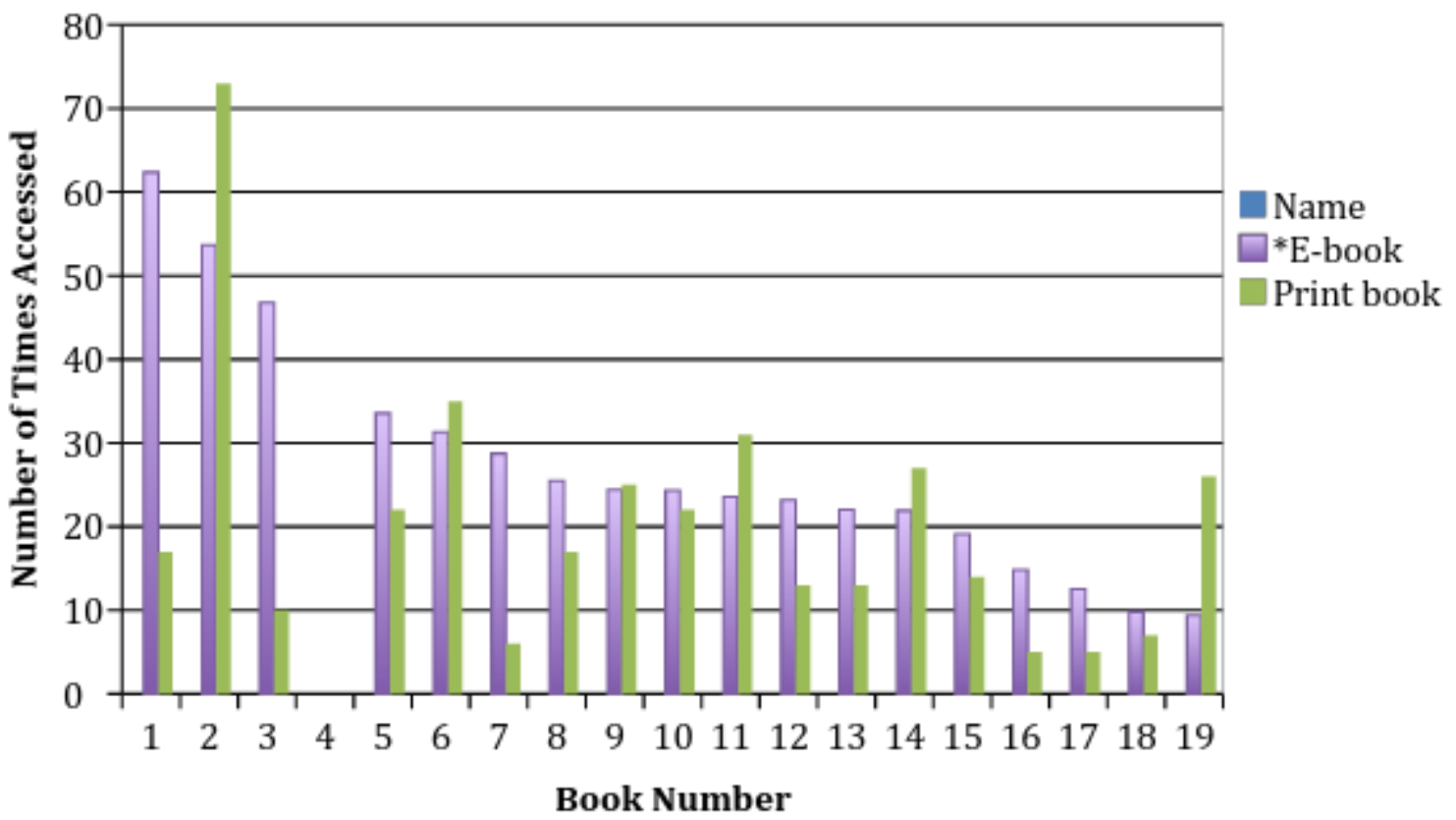

*E-book access has been divided by 100 to allow for better comparison.

Table 1.

Title comparison for E-book and Print Book Access

\begin{tabular}{|l|l|l|l|}
\hline $\begin{array}{l}\text { Book } \\
\#\end{array}$ & $\begin{array}{l}\text { E-book } \\
\text { Sessions }\end{array}$ & $\begin{array}{l}\text { Print } \\
\text { Circulations }\end{array}$ & $\begin{array}{l}\text { E-book to Print } \\
\text { Ratio }\end{array}$ \\
\hline 2 & 54 & 73 & $3: 4$ \\
\hline 5 & 34 & 22 & $3: 2$ \\
\hline 7 & 29 & 6 & $5: 1$ \\
\hline 12 & 23 & 13 & $9: 5$ \\
\hline 14 & 22 & 27 & $4: 5$ \\
\hline 17 & 13 & 5 & $5: 2$ \\
\hline 18 & 10 & 7 & $7: 5$ \\
\hline
\end{tabular}

Table 2.

Comparison of Single-Copy Print Books and the E-book Format

\begin{tabular}{|l|l|l|l|}
\hline $\begin{array}{l}\text { Book } \\
\#\end{array}$ & E-book & Print & E-book to Print \\
Sessions & Circulations & Ratio \\
\hline
\end{tabular}




\begin{tabular}{|l|l|l|l|}
\hline 1 & 62 & 17 & $4: 1$ \\
\hline 3 & 47 & 10 & $5: 1$ \\
\hline 7 & 29 & 6 & $5: 1$ \\
\hline 12 & 23 & 13 & $9: 5$ \\
\hline 16 & 15 & 5 & $3: 1$ \\
\hline 17 & 13 & 5 & $5: 2$ \\
\hline
\end{tabular}

Table 3.

E-book View Counts in Relation to Number of Titles

\begin{tabular}{|l|l|l|}
\hline $\begin{array}{l}\text { Number of } \\
\text { Views }\end{array}$ & $\begin{array}{l}\text { Number of } \\
\text { titles }\end{array}$ & $\begin{array}{l}\text { Percentage of } \\
\text { Holdings }\end{array}$ \\
\hline 1 & 1,751 & $17.5 \%$ \\
\hline $2-5$ & 2136 & $21.3 \%$ \\
\hline $6-10$ & 1307 & $13.0 \%$ \\
\hline $11-99$ & 3725 & $37.2 \%$ \\
\hline $100-999$ & 969 & $9.6 \%$ \\
\hline $1000-2999$ & 100 & $1.0 \%$ \\
\hline$>3000$ & 18 & $.18 \%$ \\
\hline
\end{tabular}

Table 4.

Turnaway Rates for Most-Accessed Single-Title E-books

\begin{tabular}{|c|c|c|}
\hline Titles & $\begin{array}{c}\text { Turnaways between } 1 / 1 / 13 \\
\text { and } 10 / 1 / 14\end{array}$ & $\begin{array}{l}\text { Total Print } \\
\text { Copies }\end{array}$ \\
\hline $\begin{array}{c}\text { Language, Culture, and Teaching: Critical Perspectives for a } \\
\text { New Century (2nd ed.) }\end{array}$ & 13 & 3 \\
\hline Learning about Learning Disabilities (4th ed.) & 15 & 0 \\
\hline Regression Analysis by Example (4th ed.) & 14 & 0 \\
\hline $\begin{array}{l}\text { Funds of Knowledge: Theorizing Practices in Households, } \\
\text { Communities, and Classrooms }\end{array}$ & 11 & 3 \\
\hline $\begin{array}{l}\text { Second Language Acquisition: An Introductory Course (3rd } \\
\text { ed.) }\end{array}$ & 1 & 0 \\
\hline
\end{tabular}

Table 5.

Cost comparison between Print and E-book Titles 


\begin{tabular}{|c|c|c|c|c|}
\hline \# & Title & $\begin{array}{l}\text { Print Book } \\
\$\end{array}$ & $\begin{array}{c}\text { E-book Single Access } \\
\$\end{array}$ & $\begin{array}{c}\text { E-book Multi Access } \\
\$\end{array}$ \\
\hline 1 & $\begin{array}{c}\text { Evidence-Based Educational } \\
\text { Methods }\end{array}$ & $\$ 87.43$ & $\$ 115.14$ & $\$ 172.71$ \\
\hline 2 & $\begin{array}{l}\text { Language, Culture, and Teaching: } \\
\text { Critical Perspectives for a New } \\
\text { Century (2nd ed.) }\end{array}$ & $\$ 56.00$ & $\$ 160.00$ & $\$ 200.00 *$ \\
\hline 3 & Enhancing Professional Practice & $\$ 26.03$ & $\$ 27.95$ & $\$ 41.93$ \\
\hline 4 & $\begin{array}{l}\text { Understanding by Design (Expanded } \\
\text { 2nd ed.) }\end{array}$ & $\$ 27.90$ & $\$ 32.95$ & $\$ 49.43$ \\
\hline 5 & $\begin{array}{l}\text { Funds of Knowledge: Theorizing } \\
\text { Practices in Households, } \\
\text { Communities, and Classrooms }\end{array}$ & $\$ 48.85$ & $\$ 135.00$ & $\$ 168.75^{*}$ \\
\hline
\end{tabular}

*Indicates price is for 3 -user access (unlimited access not available) 